\title{
Skill Development to Leverage Make in India: Gender and Policy Perspective
}

\author{
* Dr. A.K. Singh \\ ** Dr. G. R. Krishnamurthy \\ *** Dr. T. Jayapraksh Rao
}

\section{Abstract}

Skill development has been considered as the backbone of economic development. Entrepreneurship, skill development and new venture creation has long been a driving force in commercializing new technologies and developing new markets, creating new jobs, and growing economies. It has been well established that the level of economic growth of a region, to a large extent, depends on the level of entrepreneurial and skill development activities in the region. Government of India has launched National Skill Development Mission and National Skill Development Policy. The national policy on skill development envisages to creating opportunities for all to acquire skills throughout life and specially for youth, women and disadvantaged group, promoting commitment by all stakeholders to own skill development initiatives, developing a high quality skilled workforce, entrepreneurs relevant to emerging employment market needs. The policy has widened the scope of skill training and entrepreneurship development through utilizing the existing educational infrastructure and expansion of institutions engaged in skill training and vocational education. Government of India has also introduced several schemes, programmes and projects for providing training, vocational education and entrepreneurship development to youth, women and disadvantaged groups. In view of the high national priority, several state governments have also introduced state Policy for Skill development and established State Skill Development Mission with vision and strategic plan. Against

* Assistant Director, Regional Centre for Urban and Environmental Studies, Lucknow University Campus, Lucknow.

** Professor of Eminence, A. J. Institute of Management, Mangalore, Karnataka

*** Director , A. J. Institute of Management, Mangalore, Karnataka 
this view point, present paper purports to review the policy and gender perspective of skill development and its leverage to make in India.

Key Words : Entrepreneurship, Skill Gap, National Skill Development Corporation, Women Entrepreneurship

\section{Introduction}

Entrepreneurship has been considered as the backbone of economic development. It has been well established that the level of economic growth of a region, to a large extent, depends on the level of entrepreneurial activities in the region. The myth that entrepreneurs are born, no more holds truth, rather it is well recognized now that the entrepreneurs can be created and nurtured through appropriate interventions in the form of entrepreneurship development programmes. In the era of liberalization, privatization and globalization along with ongoing Information Technology revolution, capable entrepreneurs are making use of the opportunities emerging from the changing scenario. However, a large segment of the population, particularly in the industrially backward regions generally lags behind in taking advantage of these opportunities (Singh, 2009).Entrepreneurship development and training is one of the key elements for development of micro and small enterprises, particularly for the first generation entrepreneurs (Krishna, et.al., 2011). Though, India has improved its performance in education, however, there is growing deficit of skilled manpower (Clark, 2005). Therefore, there is a need to provide skill development and entrepreneurship development training to such population in order to mainstream them in the ongoing process of economic growth and development. Skill up gradation and entrepreneurship has been considered as the backbone of economic development (World Bank, 2006). It has been well established that the level of economic growth of a region, to a large extent, depends on the level of entrepreneurial activities in the region.

Skill development is essential for development and economic prosperity of the nation. The level of growth of a region depends on the level of entrepreneurial activities in the region (Acszolton, et.al.). 
The entrepreneurs can be created and nurtured through appropriate interventions in the form of entrepreneurship development programmes. In post economic liberalization, privatization and globalization era, capable entrepreneurs are making use of emerging opportunities unleashed by new business environment. However, a large segment of the youth population, particularly in the backward regions lags behind in taking advantage of opportunities of employment. Therefore, there is a need to provide skill development and entrepreneurship development youth in order to mainstream them in the ongoing process of economic growth and development (Dahlam, and Anuja, 2005).

Entrepreneurial skill development and training is, thus, one of the key elements for development of micro and small enterprises (MSEs), particularly, for the first generation entrepreneurs. India has over 470 million persons below the age of 18 years. India's potential to earn a demographic dividend from its burgeoning youthful population is often cited, but generally without the rider that should accompany it. India will not realize its demographic dividend unless its youth are able to earn income. The government of India is seized of the imperative to create employment opportunities for its youth through skill development. The National Skill Development Corporation is one of its kind public private partnerships in India. It aims to promote skill development by catalyzing creation of large, quality and for profit vocational institutions. Pradhan Mantri Kaushal Vikas Yojana is the flagship scheme of Government of India, implemented through National Skill Development Corporation under the Ministry of Skill Development and Entrepreneurship. Industry is also witnessing an increased participation from corporate and public sector enterprises who are coming forward and investing back in the country's youth by supporting skill development through their CSR initiatives under various partnerships such as financing, providing infrastructure, recognition of prior learning, adoption of national qualification framework and occupational standards etc. However, skill India is daunting task of keeping sight on the manpower requirement of the industry and the infrastructure needed 
for achieving the targets of skilling. Skill development is an effective tool to overcome exclusion; however, it is necessary to monitor the outcome of education, knowledge and training in terms of improvement in employability which would facilitate not only entry into labour market but also social inclusion. Skill development is not sufficient to address the problem of un-employment in India. There is also need of creating job opportunities for youth, women and particularly poor (Gupta and Singh, 2015).

Skill development is critical for economic and social development of India. It is imperative to ensure employment opportunities for more than 12 million youths entering working age annually. It was estimated that during the seven-year period of 2005-2012, only 2.7 million net additional jobs were created in the country (FICCI, 2015). In order to enable employment ready workforce in future, the youth need to be equipped with necessary skills and education. The skill development is one of the priorities of government which aims to enhance participation of youth, seek greater inclusion of women, disabled and other disadvantaged sections into the workforce, and strengthening the present system, making it flexible to adapt to technological changes and meeting the demands emanating from the labour market. Skill development efforts in India are spread across approximately 20 separate ministries, 35 State Governments and Union Territories as well as the private sector. Ministry of Skills Development, Entrepreneurship, Youth and Sports was created in 2014. The Ministry has been entrusted with the coordination of all stakeholders during the evolution of an appropriate skills development framework, removal of disconnect between demand and supply of skilled manpower, skills upgradation, building new skills, innovative thinking and assuring availability of talents. The National Policy on Skill Development was first formulated in 2009 to create a skills ecosystem in India. However, the government has introduced National Policy on Skill Development and Entrepreneurship in 2015. The policy aims to provide an umbrella framework to all skill related activities carried out within the country, to align them to common standards and link skill activities with demand centers. 


\section{Engendering Development}

Gender equality is central to the realization of Millennium Development Goals. Gender equality, leading to increased work opportunities, enhanced capacities for livelihood developments, enhanced social protection and overall increasing voice may enable women to participate equally in productive employment, contributing to women's development leading to economic growth of the nation. No nation can afford development without considering women who constitute about half of the stock of human resources. Thus, engendering growth has been internationally recognized instrument of development by incorporating gender perspective and concerns at all levels and stages of development planning, policy, programmes and delivery mechanisms. The issue of engendering development and women empowerment has been in the central stage with the shifting of paradigm of development and governance at the global level and particularly in India. Engendering development and inclusive growth requires an enabling environment in which women's contribution to the economy can be tapped and enhanced in a substantial and holistic way. This environment needs to ensure from conception to death - an environment that provides physical, emotional, economic and political and community security to girls and women. The engendered development also requires addressing the issues of accountability, capacity building and governance that are of utmost importance for gender equity and inclusive growth( Singh, and Singh, 2017). There has been paradigm shift in women development in India. During the First Five Year Plan to Fifth Five Year Plan, welfare approach was adopted for women development. During Sixth Five Year Plan, there was shift from welfare approach to development of women. During the Ninth Five Year Plan, empowerment of women was adopted as a strategy and approach for women development. During the Eleventh Five Year Plan, emphasis was given on engendering development and gender budgeting (Chart-1). 


\section{Chart 1: Gender Development in Indian Planning}

\begin{tabular}{|c|c|}
\hline $\begin{array}{l}\text { First Five Year } \\
\text { Plan (1951-56) }\end{array}$ & $\begin{array}{l}\text { Development of women was clubbed with the } \\
\text { welfare of the disadvantaged groups like destitute, } \\
\text { disabled, aged, etc. }\end{array}$ \\
\hline $\begin{array}{l}\text { Second to Fifth } \\
\text { Five Year Plans } \\
(1956-79)\end{array}$ & $\begin{array}{l}\text { Welfare approach, besides giving priority to } \\
\text { women's education, improved maternal and child } \\
\text { health services, supplementary feeding for } \\
\text { children and expectant and nursing mothers. }\end{array}$ \\
\hline $\begin{array}{l}\text { Sixth Five Year } \\
\text { Plan (1980-85) }\end{array}$ & $\begin{array}{l}\text { Shift in the approach from 'welfare' to } \\
\text { 'development' of women. Multi-disciplinary } \\
\text { approach with thrust on health, education and } \\
\text { employment. }\end{array}$ \\
\hline $\begin{array}{l}\text { Seventh Five } \\
\text { Year Plan } \\
(1985-90)\end{array}$ & $\begin{array}{l}\text { Aimed at raising women's economic and social } \\
\text { status and bringing them into the mainstream of } \\
\text { national development. The thrust was on } \\
\text { generation of both skilled and unskilled } \\
\text { employment through proper education and } \\
\text { vocational training. }\end{array}$ \\
\hline $\begin{array}{l}\text { Eighth F } \\
\text { Year Pla } \\
(1992-9\end{array}$ & on the development of women. \\
\hline $\begin{array}{l}\text { Ninth Fiv } \\
\text { Plan (199 } \\
\text { 2002) }\end{array}$ & $\begin{array}{l}\text { Attempted 'Empowerment of Women'. The Plan } \\
\text { also aimed at 'convergence of existing services' } \\
\text { available in both women-specific and women- } \\
\text { related sectors. }\end{array}$ \\
\hline $\begin{array}{l}\text { Tenth Fiv } \\
\text { Plan }(200\end{array}$ & $\begin{array}{l}\text { Continues with the strategy of "Empowering } \\
\text { Women" as an agent of social change and } \\
\text { development through Social Empowerment, } \\
\text { Economic Empowermentand Gender Justice. }\end{array}$ \\
\hline $\begin{array}{l}\text { Eleventh Five } \\
\text { Year Plan } \\
(2007-2012)\end{array}$ & $\begin{array}{l}\text { The plan proposes to undertake special measures } \\
\text { for gender empowerment and equity. The Ministry } \\
\text { of Women and Child Development would make } \\
\text { synergic use of gender budget and gender } \\
\text { mainstreaming process. }\end{array}$ \\
\hline $\begin{array}{l}\text { Twelfth Five } \\
\text { Year Plan } \\
(2012-2017)\end{array}$ & $\begin{array}{l}\text { Engendering of development planning and making } \\
\text { it more child-centric. }\end{array}$ \\
\hline
\end{tabular}

Source: Planning Commission, Govt. of India. 
There are different aspects of development in the context of gender. Women empowerment is multidimensional encompassing cultural, legal, political, economic and social aspects. In view of the economic empowerment of women, skill training entrepreneurship development and vocational education are important besides micro financing as it has direct bearing on development of women owned enterprises and employment creation (Chart-2).

Chart 2 : Different Aspects of Development in Context of Gender

\section{Skill Gap Analysis}

Skill development is critical for economic growth and social development. The demographic transition of India makes it imperative to ensure employment opportunities for more than 12 million youths entering working age annually. Skill development of the workforce is crucial, considering the demographic dividend available to us. In order to reap the benefits of this demographic dividend, skill needs to be made aspirational and multiple pathways should be provided for growth under skilling. About 62 percent of India's population is in the working age group of (15 59 years), with 54 percent of the total population below the age of 25 years. As per the skill gap studies conducted, there will be net incremental requirement 
of 109.73 million skilled persons by 2022 . About 25 percent schools will integrate skilling with formal education from class 9 onwards over the next 5 years to make skill development aspiration. One of the biggest challenges of skill development in our country is that 93 percent of the workforce is in informal/unorganized sector ( NITI Ayog, 2017).

As per the skill gap study conducted by the National Skill Development Cooperation over 2010 - 2014, there is an additional net requirement of 109.73 million skilled manpower by 2022 across twenty four key sectors. The major sectors are building and construction, beauty and wellness, retail, agriculture, transportation and logistics, and tourism and travel. In order to provide skill training and entrepreneurship development to the workforce, India has set a target of skilling 500 million people by the year 2022 (Table 1). Each State is expected to identify potential employers in cities and towns and at local, district and regional level. Sectors might include ITEs, manufacturing, construction, sales and marketing, education, health and fitness, logistics management, financial sector, office automation/management, hospitality, visual arts, gems and jewellery, health care, repairs and maintenance, tourism and adventurous sports, life styles, etc. Making a list of the employers and setting up a dialogue with sector/industry associations would be the first step to understand the skill training needs and likely number ofjobs (Singh, 2009)

Table No. 1: Incremental Human Resource Requirement 


\section{Source: Ministry of Skill Development and Entrepreneurship}


According to the Planning Commission, about 12.8 million people will join the labour market annually up to 2017 . As the proportion of the working age group of 15-59 years increases, India has the advantage of a "demographic dividend". Harnessing the demographic dividend through appropriate skill development efforts would provide an opportunity to achieve inclusion and enhance productivity within the country and also effect a reduction in global skill shortages. More than 700 million Indians are estimated to enter the working age group by 2022, of which more than 500 million will require some form of vocational or skill training. Large scale skill development is thus an imminent imperative (NSDC, 2013). The government has identified 20 high-growth sectors and services that have the ability to provide expanded employment in the coming years; of which 10 are in manufacturing and an equal number are in services. The most prominent sectors are manufacturing, textiles, construction, automotive and healthcare. It is necessary to develop proper skill training mechanisms, as the skill sets required in manufacturing and services sectors differ significantly from those required in the agriculture sector- the existing majority employer (IBEF, 2013).

Incremental skill gap across various industries in India in 2022 has been estimated to be 347 million. Out of this, infrastructure, domestic help, beauticians, security guards, auto and auto components, building and construction industry, textile and clothing and transportation and logistics are likely to contribute significantly in the incremental skill requirements (Table No.2).

Table No. 2 : Incremental Skill Gap across Various Industries in India in $\mathbf{2 0 2 2}$ 
Considering the diversity of skill requirements across various leveis for construction, chemicals and pharmaceuticals, construction materials and building hardware, electronics and IT hardware industry, food processing sector, furniture \& furnishing industry, gems and jewellery industry, leather industry, organized retail and 
textile and clothing industry; a skill pyramid for the industry as a whole has been created considering the weighted averages. The skill pyramid, in summary, captures where the overall industry stands relatively in terms of skills (a function of activity, educational requirements and the amount of 'preparatory' time required to inculcate a specific skill). As can be observed, the lower portion of the pyramid, 'Skill level 1', has the highest incremental requirement of human resources. It requires persons who are minimally educated, but can still handle simple and/or repetitive tasks (e.g., persons such as cutters, those engaged in polishing, etc). Such skills can also be attained in a lesser time duration as compared to engineering or ITI. Skill level 2 relates to areas where substantial skill building efforts would be needed (e.g., carpenters, electricians, welders, operators, plumbers). In the 10 sectors listed below, as many as 370 million persons are required across various skill levels outlined above by 2022. Out of this, Skill level 1 account for over 66 per cent of the human resources with skilling requirements (CII, 2015). As per Manpower Talent Shortage Survey conducted by OECD in 2014, India has the second greatest shortage of skill after Japan in the world .about 64 percent skill shortage was reported in India while skill shortage was reported 81 percent in Japan, 63 percent in Brazil, 63 percent in Turkey and 40 percent in Germany and 40 percent in United States. It was reported negligible in Spain (3 percent).

Skill Level 1 (L1) refers to skills that require minimal education and can be acquired through on-the-job training, short-term modular courses and focused interventions. Skill Level 2 (L2) refers to skills that can be acquired through technical/vocational training or trade certificates, and are specific to the occupation, such as knowledge of complex operations and machinery, skills of supervision, etc. Skill Level 3 (L3) refers to skills which require long drawn preparations through acquisitions of degrees, diplomas and post graduate education. These skills require highly technical or commercial operations. Skill Level 4 (L4) are highly specialized skills involving research and design which can be gained through $\mathrm{PhD}$ or post doctoral work and extensive work experience.L1 and L2 are called the "Bottom of the Skill Pyramid" as they constitute the "minimally 
skilled" workforce (Athena Infonomics,2017) .As per NSDC data, more than 70 percent of the industry workforce requirement comprises of the bottom of the pyramid skills, and hence this policy brief will focus on providing skill development and training for this Bottom of the Skill Pyramid (Table No. 3).

Table No. 3 : Skill Requirement Across Sectors

\begin{tabular}{|c|c|c|c|c|c|}
\hline Seg ment & $\begin{array}{c}\text { Skill } \\
\text { level 1 }\end{array}$ & $\begin{array}{c}\text { Skill } \\
\text { level 2 }\end{array}$ & $\begin{array}{c}\text { Skill } \\
\text { level 3 }\end{array}$ & $\begin{array}{c}\text { Skill } \\
\text { level 4 }\end{array}$ & $\begin{array}{c}\text { Total } \\
\text { Employment in } \\
\text { 2022 in '000s }\end{array}$ \\
\hline $\begin{array}{c}\text { Construction } \\
\text { industry }\end{array}$ & $80-81 \%$ & $14-15 \%$ & $3-4 \%$ & $1-2 \%$ & 83,270 \\
\hline $\begin{array}{c}\text { Chemicals and } \\
\text { pharmaceuticals }\end{array}$ & $20-25 \%$ & $25-30 \%$ & $44-45 \%$ & $5-6 \%$ & 3,548 \\
\hline $\begin{array}{c}\text { Construction } \\
\text { materials and } \\
\text { building hardware }\end{array}$ & $35-40 \%$ & $40-45 \%$ & $15-18 \%$ & $2-5 \%$ & 2,497 \\
\hline $\begin{array}{c}\text { Electronics and IT } \\
\text { hardware industry }\end{array}$ & $19-21 \%$ & $25-27 \%$ & $49-50 \%$ & $4-5 \%$ & 4,129 \\
\hline $\begin{array}{c}\text { Food processing } \\
\text { sector }\end{array}$ & $80-81 \%$ & $9-10 \%$ & $8-9 \%$ & $1-2 \%$ & 17,808 \\
\hline $\begin{array}{c}\text { Furniture and } \\
\text { furnishing industry }\end{array}$ & $80 \%$ & $12 \%$ & $7 \%$ & $1 \%$ & 4,873 \\
\hline $\begin{array}{c}\text { Gems and } \\
\text { jewellery industry }\end{array}$ & $74-75 \%$ & $4-5 \%$ & $18-20 \%$ & $1-3 \%$ & 7,943 \\
\hline $\begin{array}{c}\text { Leather industry } \\
\text { Organized retail }\end{array}$ & $88.5-$ & $4-4.5 \%$ & $6-6.5 \%$ & $0.5-1 \%$ & 7,139 \\
\hline $\begin{array}{c}\text { Textile and } \\
\text { clothing industry }\end{array}$ & $85-86 \%$ & $10-11 \%$ & $3-3.5 \%$ & $0.5-1 \%$ & 61,600 \\
\hline Industry average & $66.0 \%$ & $12.6 \%$ & $18.5 \%$ & $2.9 \%$ & 369,059 \\
\hline
\end{tabular}

Source: IMaCS Research

Key skills demand for selected sectors is shown in Table 4. Both hard skills and soft skills would be required for industrial growth and development. Soft skills would be required mainly in information 
technology, KPO and BPO industries while hard skills would be required in other manufacturing sectors. Even traditional skills would be required for food processing, textile and clothing, building and construction, gems and jewellery, leather and leather goods, tourism and hospitality services, etc.

\section{Table No. 4 : Skills in Demand in Select Sectors}

\begin{tabular}{|c|c|}
\hline Sector & Key skills in demand \\
\hline $\begin{array}{l}\text { Textiles and } \\
\text { clothing }\end{array}$ & $\begin{array}{l}\text { Power loom operators, apparel manufacturing, } \\
\text { fashion design, QA, knitwear manufacturing, } \\
\text { sewing machine operators }\end{array}$ \\
\hline $\begin{array}{l}\text { Building and } \\
\text { construction } \\
\text { industry }\end{array}$ & $\begin{array}{l}\text { Crane operators, electricians, welders, masons, } \\
\text { plumbers, carpenters, painters, etc. }\end{array}$ \\
\hline $\begin{array}{l}\text { Auto and auto } \\
\text { components }\end{array}$ & $\begin{array}{l}\text { Auto OEMs, auto component manufacturers, } \\
\text { drivers, sales, servicing, repair, financial services } \\
\text { sales, insurers/valuers }\end{array}$ \\
\hline $\begin{array}{l}\text { Organized } \\
\text { retail }\end{array}$ & $\begin{array}{l}\text { Shop floor executives, back-store operations, } \\
\text { merchandising }\end{array}$ \\
\hline $\begin{array}{l}\text { Banking, } \\
\text { financial } \\
\text { services and } \\
\text { insurance }\end{array}$ & $\begin{array}{l}\text { Financial intermediaries (including direct selling } \\
\text { agents), banking and insurance (including agents), } \\
\text { NBFCs, mutual funds }\end{array}$ \\
\hline $\begin{array}{l}\text { Gems and } \\
\text { jewellery }\end{array}$ & $\begin{array}{l}\text { Jewellery fabrication, grading, faceting, polishing, } \\
\text { cutting }\end{array}$ \\
\hline IT and ITeS & $\begin{array}{l}\text { IT - Software engineering, maintenance and } \\
\text { application development, end-to-end solutions, } \\
\text { infrastructure management, testing, etc } \\
\text { ITeS-BPO, KPO-Legal, medical, STM, analytics } \\
\text { and research }\end{array}$ \\
\hline $\begin{array}{l}\text { Leather and } \\
\text { leather goods }\end{array}$ & $\begin{array}{l}\text { Tanning, cutting, clicking, stitching, lasting, } \\
\text { finishing }\end{array}$ \\
\hline $\begin{array}{l}\text { Furniture and } \\
\text { furnishings }\end{array}$ & $\begin{array}{l}\text { Carpenters \& operators engaged in stitching, } \\
\text { sewing, stuffing }\end{array}$ \\
\hline
\end{tabular}




\begin{tabular}{|c|c|}
\hline $\begin{array}{l}\text { Electronics and } \\
\text { IT hardware }\end{array}$ & $\begin{array}{l}\text { Computers, telecom \& consumer electronics; } \\
\text { manufacturing, sales, servicing/after sales } \\
\text { support of electronics goods; high-tech }\end{array}$ \\
\hline $\begin{array}{l}\text { Tourism and } \\
\text { hospitality } \\
\text { services }\end{array}$ & $\begin{array}{l}\text { Front office staff, F\&B services and kitchen and } \\
\text { housekeeping staff, ticketing and sales, tour } \\
\text { guides }\end{array}$ \\
\hline $\begin{array}{l}\text { Chemicals and } \\
\text { pharmaceuticals }\end{array}$ & $\begin{array}{l}\text { Industrial and chemical manufacturing } \\
\text { attendants, process attendants, manufacturing } \\
\text { assistants, lab attendants, equipment operators, } \\
\text { sales personnel }\end{array}$ \\
\hline $\begin{array}{l}\text { Food processing } \\
\text { sector }\end{array}$ & $\begin{array}{l}\text { Operation of power machine, packaging, bakery, } \\
\text { cold storage and transportation, ice-cream } \\
\text { manufacturing, slaughtering, preservation } \\
\text { techniques, disposal, drying/radiation, } \\
\text { preparation of concentrates, manufacturing of } \\
\text { edible oil }\end{array}$ \\
\hline Healthcare & Doctors, nurses, technicians and paramedics \\
\hline $\begin{array}{l}\text { Media and } \\
\text { entertainment }\end{array}$ & $\begin{array}{l}\text { Directors, cinematographers, editors, script } \\
\text { writers, artists, producers, s o und } \\
\text { designers/editors, animation - pre-production, } \\
\text { animator, game developer, radio jockey }\end{array}$ \\
\hline $\begin{array}{l}\text { Transportation, } \\
\text { logistics, } \\
\text { warehousing } \\
\text { and packaging }\end{array}$ & $\begin{array}{l}\text { Truck drivers, loading supervisors, warehouse } \\
\text { managers, pilots, aircraft maintenance, air traffic } \\
\text { control, instructors, safety and security }\end{array}$ \\
\hline
\end{tabular}

\section{Source: IMaCS Research}

It is estimated that during the seven-year period of 2005-2012, only 2.7 million net additional jobs were created in the country. To enable employment ready workforce in the future, the youth need to be equipped with necessary skills and education (Chenoy, 2012). India lacks marketable skills. The lack of marketing skills was found more pronouncing in rural areas as compared to urban areas. Women are lagging behind as far as attainment of marketable skills is concerned. Again, marketable skills were found higher among women from urban areas as compared to women from rural areas (Table No. 5). 
Table No. 5 : Distribution of Persons with Marketable Skills

(Figures in Percentage)

\begin{tabular}{|c|c|c|c|c|}
\hline Skill Status & \multicolumn{2}{|c|}{ Rural } & \multicolumn{2}{c|}{ Urban } \\
\hline & Men & Women & Men & Women \\
\hline No Skill & 89.9 & 93.7 & 80.4 & 88.8 \\
\hline Some Skill & 10.1 & 6.3 & 19.6 & 11.2 \\
\hline Total & 100.0 & 100.0 & 100.0 & 100.0 \\
\hline Sample Size & 183464 & 172835 & 109067 & 99283 \\
\hline
\end{tabular}

Source: Amit Mitra, 2012

The skill development ecosystem in India is skewed towards a formal education system with limited vocational training. While the vocational training is in a dismal state both qualitatively and quantitatively, the higher education system itself is grappling with issues related to scale and quality. Skill development efforts in India are spread across approximately 20 separate ministries, 35 State Governments and Union Territories and the private sector. A Ministry of Skills Development, Entrepreneurship, Youth and Sports was created when the Modi government took charge in mid-2014.The Ministry has been entrusted with the coordination of all stakeholders during the evolution of an appropriate skills development framework, removal of disconnect between demand and supply of skilled manpower, skills upgradation, building new skills, innovative thinking and assuring availability of talents ( FICCI, 2015). The National Policy on Skill Development was first formulated in 2009 to create a skills ecosystem in India. It acts as a guide to formulate strategies by addressing the different challenges in skill development. The government has introduced a National Policy on Skill Development and Entrepreneurship, 2015. The policy aims to provide an umbrella framework to all skill related activities carried 
out within the country, to align them to common standards and link skill activities with demand centres. In addition to laying down the objectives and expected outcomes, it aims at identifying various institutional frameworks which can act as the vehicle to reach the expected outcomes. The new skills policy also provides details on how skill development efforts across the country can be aligned within the existing institutional arrangements (MSDE, 2015). There are 21 Ministries under the central government who are also working for the purpose of skill development. There are two approaches that these Ministries have: one approach is setting up training centres of their own for specific sectors like (adopted by Ministry of Labour \& Employment, Ministry of Agriculture, Ministry of Health \& Family Welfare, etc.). The second approach is in the form of Public Private Partnership (as adopted by Ministry of Rural Development, Ministry of Women and Child Development, etc.). National Skill Development Council has been established with a central government commitment of Rs 10 billion and Rs 150 billion is envisaged to be generated from other governments, public sector entities, and private sector players, bilateral and multilateral sources. The government has, however, further increased the allocation of funds in the Union Budget 2012-13 by Rs 10 billion, taking the total corpus to Rs 25 billion.

The National Skill Development Corporation India (NSDC) is a public private partnership organisation (now under the Ministry of Skill Development and Entrepreneurship) that was incorporated in 2009 under the National Skill Policy. Its main aim is to provide viability gap funding to private sector in order to scale up training capacity. Of the 500 million targeted to be skilled under the National Skill Development Policy 2009, the National Skill Development Corporation (NSDC) was mandated to skill 150 million, while the Directorate General of Employment and Training (DGET), under the Ministry of Labour and Employment was to skill 100 million (Okada,2012). Most of the ministries are lagging behind in achieving the targets of skill training. During 2014-15, about half of the targets were achieved by various ministries for providing skill training (Table No. 6). 
Table No. 6 : Schemes Implemented By Various Ministries YearTarget

(in Lakhs)

\section{Table No. 7 : Numbers of ITIs with Total Seating Capacity}

Number of it is with total seating capacity is shown in Table 7. As per information available, 11964 ITIs with the seating capacity of 16.93 lakh students were reported in India. Out of total ITIs, 38.20 per cent ITIs were located in North India while 29.20 per cent ITIs were found situated in South India. There has been impressive growth in technical institutions in India however, the pace of growth of institutions is found higher as compared to the growth in the seating capacity of students in India. The academic infrastructure in most of 
the technical and academic institutions is under utilization and therefore, it is imperative to ensure effective use of available infrastructure for skill training through collaboration with private training institutions.

\section{Women Entrepreneurs}

Women Entrepreneur is classified into three categories, i.e. women employer, women own account workers and bosses wives. These categories are based on, how the women started their business with the help of others. Women employers refers to those women who provide work opportunities to paid employees. Women own account workers are those self- employed business owners who do not hire employees. Bosses wives are referring those women who normally hide behind their husbands but are the real managers of their husbands business. Women entrepreneurs make a significant contribution to the Indian economy ( Verma, 2015). There are nearly three million micro, small, and medium enterprises with full or partial female ownership. These women-owned enterprises contribute 3.09 percent of industrial output and employ over 8 million people (Trivedi and Gaur, 2015).

Table No. 8 : Classification of Women-Owned MSMEs

Most of the women owned MSMEs were found unregistered (89.50 per cent). The proportion of unregistered units was recorded high in macro enterprises (90.64 per cent). Out of total women owned enterprises, 97.62 per cent enterprises were categorized as micro 
enterprises. About 10 per cent MSMEs were constituted women owned MSMEs (Table No. 8).

Benefits of women entrepreneurship are shown in Table No. 9. A women entrepreneur significantly contributes in the economy of the nation. Entrepreneurship builds confidence among women while their social and economic status significantly improves. Moreover, women entrepreneurs contribute significantly in the income of family and thus, there is more scope for development of children and creation of household assets.

Table No. 9 : The Benefits of Women EntrepreneurshipEmpowerment 
Overall, $1 / 3^{\text {rd }}$ registered units consisted of women enterprises. This was found slightly high in the state of Uttar Pradesh (39.84 per cent) followed by Gujarat (39.72 per cent) and Kerala (38.91 per cent) (Table No. 10).

Table No. 10 : Women Entrepreneurship in India

Approximately, 78 percent of women enterprises belong to the services sector. Women entrepreneurship is largely skewed towards smaller sized firms, as almost 98 percent of women-owned businesses are micro-enterprises. As with the broader MSME sector, access to formal finance is a key barrier to the growth of womenowned businesses, leading to over 90 percent of finance requirements being met through informal sources (Diwakar and Ahmed, 2015).

Geographical distribution of women owned MSMEs is shown in Table 11. Kerala, Karnataka, Tamil Nadu and West Bengal have a 
combined share of 51.9 per cent in the women owned MSMEs while Rajasthan, Maharashtra, Punjab, Uttar Pradesh, Bihar, Gujarat and Odisha with the combined share of 26.7 per cent were categorized as low prevalence of women owned businesses in India.

\section{Table No. 11 : Geographical Distribution Of Women-Owned} MSMEs

The total finance requirement of women-owned MSMEs in 2012 was around Indian Rs. 8.68 trillion ( $\$ 158$ billion). Within the segment, small enterprises led the demand for financing: around Indian Rs 6.42 trillion ( $\$ 116$ billion), approximately 74 percent of the total requirement. This was mostly due to unmet working capital and investment finance needs. Micro enterprises with a requirement of Indian rupees 2.05 trillion ( $\$ 37$ billion), accounted for 24 percent. Most of this requirement was largely focused around working capital needs (Table 12). Women-owned medium-scale enterprises, which account for 0.01 percent of the total MSME sector had finance requirements of around Indian rupees 0.21 trillion ( $\$ 4$ billion), about 2 percent of the total requirement (IFC, 2014). 


\section{Table No. 12 : Demand for Financing from Women-Owned MSMEs}

\begin{tabular}{|c|c|c|c|c|}
\hline & \multicolumn{2}{|c|}{ Formal Sector } & \multicolumn{2}{c|}{ Informal Sector } \\
\hline Type & $\begin{array}{c}\text { Number of } \\
\text { units } \\
\text { (in thousands) }\end{array}$ & $\begin{array}{c}\text { Financing } \\
\text { demand Indian } \\
\text { rupees trillion } \\
\text { (\$ billion) }\end{array}$ & $\begin{array}{c}\text { Number of } \\
\text { units } \\
\text { (in thousands) }\end{array}$ & $\begin{array}{c}\text { Financing } \\
\text { demand Indian } \\
\text { rupees trillion } \\
\text { (\$ billion) }\end{array}$ \\
\hline Micro & 274.06 & $0.19(3.49)$ & $2,655.32$ & $1.86(33.86)$ \\
\hline Small & 47.53 & $3.91(71.16)$ & 30.41 & $2.50(45.54)$ \\
\hline Medium & 0.28 & $0.21(3.75)$ & 0.00 & $0.00(0.00)$ \\
\hline Total & $\mathbf{3 2 1 . 8 6}$ & $\mathbf{4 . 3 1 ( 7 8 . 4 0 )}$ & $\mathbf{2 , 6 8 5 . 7 3}$ & $\mathbf{4 . 3 7 ( 7 9 . 4 0 )}$ \\
\hline
\end{tabular}

Source: Women Owned Business in India

\section{Skill Development Schemes}

Pradhan Mantri Kaushal Vikas Yojana: PMKVY is the flagship outcome-based skill training scheme of the new Ministry of Skill Development \& Entrepreneurship. The objective of this skill certification and reward scheme is to enable and mobilize a large number of Indian youth to take up outcome based skill training and become employable and earn their livelihood. NSDC is the implementing agency of the PMKVY Scheme. Institutional arrangements comprising of the National Skill Development Corporation, Sector Skill Councils, Assessing Agencies and Training Providers are in place for implementation of the Scheme. There is also a target to ensure 33 percent coverage of women. Of the 1100 modular skills, 231 skills for women have been identified. The target is proposed to be achieved through dovetailing of all the skill development initiatives of the Government.

Rashtriya Mahila Kosh: The Rashtriya Mahila Kosh was established in 1993 to provide microcredit in a quasi-formal manner to the poor women for income generating, production, skill development and housing activities in order to make them economically independent. Rashtriya Mahila Kosh mainly channelises its support through NGOs, Voluntary agencies, States Women Development Corporations, Cooperative Societies, State Government agencies, Urban Women Co-op Banks etc. to the women SHGs. This will 
enable it to reach out to a larger number of poor, asset less and marginalised women for income generating, production, skill development and housing activities ( Ponsindhu and Nirmala, 2014).

Support to Training and Employment Program: The Ministry MWCD implements the Support to Training and Employment Programme for Women (STEP) as a Central Sector Scheme mostly through NGOs. The scheme has been in existence since 1986-87 and aims at sustainable employment and income generation for marginalized and asset less rural and urban women. The key strategies for achieving the goal of livelihood opportunities for women, especially those in SC/ST households and families below poverty line, include training for skill upgradation, facilitating organisation of women into viable cooperative groups, strengthening backward and forward linkages and providing access to credit.

Deen Dayal Upadhyaya Gramin Kaushal Yojana: The Skill component of NRLM, Aajeevika Skills, has been revamped as the Deen DayalUpadhyaya- Grameen Kaushalya Yojana. The minimum entry age for the scheme has been reduced to 15 years. The scheme encompasses (1) Credit Support Programme ; (2) Rajiv Gandhi Udyami Mitra Yojana ; (3) Prime Minister's Employment Generation Programme; and (4) Work shed Scheme for Khadi Artisans.

Trade Related Entrepreneurship Assistance And Development Scheme For Women: With a view to encourage women in setting up their own ventures, government implements a Scheme, namely, "Trade Related Entrepreneurship Assistance and Development (TREAD) during the 11th Plan. The scheme envisages economic empowerment of women through the development of their entrepreneurial skills in nonfarm activities. In India, skills are divided into different categories based on the level and duration of training required. As per the classification adopted by the National Skill Development Council, skills are classified into four levels.

\section{Skill Development Initiatives}

About 20 ministries of the Union Government of India have created infrastructure for skill development in their respective areas. These 
ministries have either set up their own training centres in specific sectors (examples of such ministries include Ministry of Labour and Employment, Ministry of Agriculture, and Ministry of Health and Family Welfare) or provided subsidized training to specific target populations (examples of such ministries include Ministry of Rural Development, and Ministry of Women and Child Development). Most state governments have also set up SSDMs as nodal bodies to anchor the skill development agenda in the state. State governments have been actively promoting vocational training by forging alliances with private partners and creating employment opportunities for the state population. In the past few years, certain initiatives taken by a few states have been appreciated by various agencies and been replicated by other states. The government has identified 20 high-growth sectors and services that have the ability to provide expanded employment in the coming years; of which 10 are in manufacturing and an equal number are in services. The most prominent sectors are manufacturing, textiles, construction, automotive and healthcare. It is necessary to develop proper skill training mechanisms, as the skill sets required in manufacturing and services sectors differ significantly from those required in the agriculture sector- the existing majority employer. Construction industry, auto sector, textile, retail, transport, healthcare and the unorganised sector in general, are few of the highest employment generating sectors. Year-on-year growth in employment, however, is high in organised retail, healthcare, IT, electronics and media \& entertainment. The Commissionerate of Employment \& Training, Government of Gujarat implements various skill building programmes with the objective of employment, which would in-turn facilitate industrial development. One of the key schemes launched for skill development has been the Kaushalya Vardhan Kendra. It is an institution to impart desired skill training at the door steps of the rural population. The main thought behind such Kendra was that if the trainees did not go to the institutes, the institutes should go to the trainees (Govt. of Gujarat, 2017). The Kerala Academy for Skills Excellence (KASE) has been set up as a non-profit company, fully owned by the Government of Kerala as an apex institution to initiate, 
implement, regulate and coordinate focused specialty skill development initiatives for different industry domains in the state such as construction, retail, finance, IT \& ITeS, tourism, and hospitality. It proposes to form separate special purpose vehicles (SPVs) using the PPP model under an apex body (Table 13).Karnataka is a leading state in the establishment of knowledge based industries such as Information Technology, biotechnology and engineering, and also in the exports of electronics, computer software and so on. The National Skill Development Corporation estimated that the incremental demand for the workforce in Karnataka during the period 2012 to 2022 is 84.76 lakhs; of them, 27 percent are minimally skilled, 43 percent are semi-skilled, 25 percent are skilled and 5 percent are highly skilled. Educational infrastructure in Karnataka is impressive. However, shortage in the institutional infrastructure providing skill training for the sectors of agriculture \& allied, Building, construction and real estate, Tourism, travel, hospitality and trade, Transportation, logistics, warehousing and packaging, and health care services that are projected to employ bulk of the workers in the coming years ( Govt. of Karnataka, 2016). Institutional infrastructure for vocational education in construction, tourism, travel, hospitality, transportation and health care services need to be improved in the coming years. Rural Development and Self Employment Training Institute (RUDSETI), is a unique initiative in mitigating the problem of unemployment, which was taken in a small village Ujire near Dharmasthala in Karnataka way back in 1982 jointly by Sri Dharmasthala Manjunatheshwara Educational Trust and two nationalized banks viz., Syndicate Bank and Canara Bank. RUDSETI was registered under Karnataka Societies Registration Act, 1960. Encouraged by the success of Ujire experiment, RUDSETI has now established 27 units in 16 States. RUDSETI offers around 70 types of Entrepreneurship Development Programs in various areas (Ramakishna and Sudhakar, 2015). All the programs are of short duration intervention ranging from one to six weeks. Udyogini is an innovative scheme, sanctioned by the Government of Karnataka through the State Women Development Corporation during the year1997-98. Udyogini assists women in 
gaining self reliance through self employment in business and economic activities. Udyogini empowers women by providing loans through banks and other financial institutions. It also grants financial aid from the Karnataka State Women Development Corporation for undertaking small business activities. The financial aid is arranged through like commercial banks and RRBs. This scheme has gone a long way in preventing women entrepreneurs from taking financial help from money lenders at high rate of interest. Under this scheme, the maximum cost is Rs. one lakh, age limit for beneficiaries is 18-45 years and family income limit to avail this benefit is Rs.40,000 per annum for all the women including those belonging to SC/ST. Karnataka State Women Development Corporation provides a financial subsidy to women who have lost and deserted by their husbands and to those who are also physically handicapped. The entrepreneurial activities supported under Udyogini scheme include book binding, sari and embroidery works, ribbon making, dry fish trade, footwear manufacture, beauty parlour, gift articles, flower shops, vegetables and fruit vending, canteen and catering, cut piece cloth trade, flour mills, toy making and photocopying service, fax paper manufacture, travel agencies, kirana shops, animal husbandry, photo studio, stationary shop, bangles, fish stalls, canteen services, provision stores, panipuri, chicken centres, poultry centres, mobile and service centres etc (Prabhavathyi and Basav Raja, 2016).

Table No. 13 : Key Initiatives by Certain States

\begin{tabular}{|c|c|}
\hline State & \multicolumn{1}{|c|}{ Skill Development Initiative } \\
\hline \multirow{3}{*}{ Karnataka } & $\begin{array}{l}\text { Converted district employment exchanges into } \\
\text { human resource development centres with } \\
\text { services like career counselling, training for soft } \\
\text { skills as well as placement }\end{array}$ \\
\cline { 2 - 3 } & $\begin{array}{l}\text { Entered into Memorandums of Understanding } \\
\text { (MoUs) with foreign universities/institutes for } \\
\text { training of trainers with international certification }\end{array}$ \\
\hline
\end{tabular}




\begin{tabular}{|c|c|}
\hline \multirow[t]{2}{*}{ Gujarat } & $\begin{array}{l}\text { - Skill voucher scheme to induce competition } \\
\text { among training providers and provide choices to } \\
\text { trainees }\end{array}$ \\
\hline & $\begin{array}{l}\text { - Kaushalya Vardhan Kendra for dealing with } \\
\text { women specific soft skills training useful to local } \\
\text { requirements }\end{array}$ \\
\hline \multirow{2}{*}{$\begin{array}{l}\text { Andhra } \\
\text { Pradesh }\end{array}$} & $\begin{array}{l}\text { - Biometric attendance check for monitoring } \\
\text { trainees }\end{array}$ \\
\hline & $\begin{array}{l}\text { - Setting up of Mission/Sub-Missions with targeted } \\
\text { beneficiaries }\end{array}$ \\
\hline \multirow[t]{2}{*}{$\begin{array}{l}\text { Madhya } \\
\text { Pradesh }\end{array}$} & $\begin{array}{l}\text { - ITIs/ITCs rating based on the certain } \\
\text { performance parameters }\end{array}$ \\
\hline & $\begin{array}{l}\text { - Training housemaids to use kitchen appliances } \\
\text { and cooking }\end{array}$ \\
\hline \multirow{2}{*}{ Rajasthan } & $\begin{array}{l}\text { - Providing training in remote areas using mobile } \\
\text { vans }\end{array}$ \\
\hline & - Developed e-learning material in local language \\
\hline Haryana & $\begin{array}{l}\text { - Use of 'video recording' for Assessment under } \\
\text { SDI Scheme, to cross verify the genuineness of } \\
\text { assessment before result declaration }\end{array}$ \\
\hline Kerala & $\begin{array}{l}\text { Focus on training specific to local requirements/ } \\
\text { resources like services sector, precision farming, } \\
\text { nano technology, etc. }\end{array}$ \\
\hline Orissa & $\begin{array}{l}\text { - Fixing minimum placement requirement for } \\
\text { selecting training providers and giving bonus for } \\
\text { higher placement above the minimum requirement }\end{array}$ \\
\hline
\end{tabular}

Source: IMaCS Research

In the private sector, initiatives for skill development have been undertaken by industry associations, industry players as well as international players. Industry associations are also involved in skill development initiatives. FICCI launched The FICCI Skills Development Forum (SDF) in 2008 to supplement government 
initiatives with industry interventions and international collaborations (Table No. 14). CII has skill development projects running across the rural and urban areas of the country. It has successfully completed over 20 projects and currently has several projects running in the rural areas of Maharashtra, Andhra Pradesh, Rajasthan, Haryana, Tamil Nadu and Punjab. It has taken up 'skills gap' studies across states and sectors, and also taken up skill development beyond borders in countries like Afghanistan ( IBEF, 2013).

Table No. 14 : Private Sector Initiatives

\begin{tabular}{|c|c|}
\hline \multirow{2}{*}{$\begin{array}{l}\text { Canara } \\
\text { Bank }\end{array}$} & Training, production and marketing centre \\
\hline & $\begin{array}{l}\text { - First promoted Training, Production and Marketing } \\
\text { Centre in } 1991 \text { at Jogaradoddi, Karnataka State. }\end{array}$ \\
\hline & $\begin{array}{l}\text { - Imparts free residential long-term skill-EDP training } \\
\text { in traditional crafts such as wood and stone carving, } \\
\text { sheet metal embossing, and terracotta. }\end{array}$ \\
\hline & $\begin{array}{l}\text { - Training provided to artisans under the supervision of } \\
\text { master craftsmen, to pursue crafts as a profession. }\end{array}$ \\
\hline & $\begin{array}{l}\text { - Trainees should be in the age group of } 18-35 \text { with } \\
\text { minimum educational qualification of } 8 \text { th std. }\end{array}$ \\
\hline & $\begin{array}{l}\text { - Preference: To applicants from rural areas, Scheduled } \\
\text { Castes/Scheduled Tribes and weaker sections of } \\
\text { society. }\end{array}$ \\
\hline & $\begin{array}{l}\text { - Inspired by its success, Canara bank opened centres } \\
\text { in Karkala, North Karnataka in } 1997 \text { and Karaikudi, } \\
\text { Tamil Nadu in } 2005\end{array}$ \\
\hline \multirow{2}{*}{$\begin{array}{c}\text { Taj } \\
\text { Hotels }\end{array}$} & Started corporate sustainability initiative in India. \\
\hline & $\begin{array}{l}\text { Taj Hotels initiative undertakes the following action } \\
\text { plan: }\end{array}$ \\
\hline
\end{tabular}




\begin{tabular}{|l|l|}
\hline & - Identification of villages \\
\hline & - Provision of food \\
\hline & $\begin{array}{l}\text { Organisation of health camps } \\
\text { pumps }\end{array}$ \\
\hline - Finance for repairing looms \\
\hline $\begin{array}{l}\text { Repayable advance for the design of Jacquard cards } \\
\text { etc. }\end{array}$ \\
\hline $\begin{array}{l}\text { Outcome: The weavers earn about US\$ } 36 \text { per saree, } \\
\text { against US\$ } 16 \text { earlier. They make more than } 5 \text { sarees a } \\
\text { month (7 days per saree compared to } 15 \text { days earlier) } \\
\text { and earn about US\$ } 180 \text { per month. }\end{array}$ \\
\hline
\end{tabular}

Source: IMaCS Research

\section{Growth of Manufacturing Sector}

Manufacturing makes a larger contribution to the GDP to enable it to sustain a growth rate of 8 percent and above. There is an effort to take the share of manufacturing from the current level of 16 percent to 25 percent of the GDP. It was recognized that India is more closely integrated with the global economy today as the share of trade as percentage of GDP is nearly 50 percent compared to about 10 percent in 1960s. The trade exposure to the outside world has shown a significant change after the initiation of economic liberalization. During 1960s to 1980s, India's total export as a share of its GDP was almost flat, being between $3-6$ percent. This ratio started increasing rapidly after 1990s. During 2010- 2014 it reached almost 25 percent, indicating deepening of integration into the global economy. This point is illustrated more starkly, if we examine the ratio of total trade to GDP. Government of India has also initiated several economic reforms and measures in recent times such as Make in India, Start up India and 'Fund of Funds for Start ups, Digital India programme, ecommerce, promoting innovation and entrepreneurship and so on. The recent passage of GST is likely to give a boost to the various reform initiatives. Make in India has been successful in attracting 
investment, especially foreign direct investment which is in the range of nearly $\$ 130$ billion since 2014. Start-up India has been responsible for creating and strengthening the eco system for Startups through a series of tax and non-tax incentives to encourage innovation and entrepreneurship. Stand-up India has been able to include a large number of women/SC/ST entrepreneurs in development of new enterprises and more than 18000 cases have been sanctioned. MUDRA scheme has been able to support crores of micro enterprises and has provided the crucial help in starting microenterprises. In order to promote manufacturing and value additions within the country, a host of schemes such as Food parks, Electronic parks, Textile package etc. have been launched. A large number of steps have been taken for ensuring that India becomes a better place to do business. As part of Ease of Doing Business initiative both state governments and central government have done considerable work (NITIAyog, 2017).

The percentage of manufacturing as a percentage of GVA has stagnated at around 16 percent for a long time and there is a need for a strong push to increase investment in manufacturing. It was seen that even FDI in manufacturing, especially in green field projects, has not been to the desired level. Manufacturing sector FDI inflows increased only 6 percent in 2015 after a 19 percent fall in 2014. In 2014, the share in total FDI was roughly equal between services, manufacturing and infrastructure, but in 2015, the share of manufacturing dropped to 27 percent. In fact, FDI into manufacturing was 15 percent lower in 2015 compared to 2013. Automobile sector have benefitted from higher FDI inflows and chemicals witnessed a 69 percent increase. On the other hand, sectors like pharma, food processing, industrial machinery, cement, electrical equipment have received lesser FDI in 2015 compared to the previous year. Thus, incremental reforms to ensure higher investment flow into the manufacturing sector is imperative to ensure a growth rate which is sustained at 8 percent and above rate for the next couple of years (NITIAgog, 2017). Agriculture, Manufacturing and Services sector contributed 15.4 percent, 20.5 percent and 64.1 
percent to India's GVA in 2015-16 respectively. Share of agriculture has seen constant decline from 18.5 percent in 2011-12 to 15.4 percent in 2015-16. Manufacturing share has stagnated at around 16 percent over the years. Services have remained the highest contributor to GDP and its share has increased gradually from 60.9 percent in 2011-12 to 64.1 percent in 2015-16(NITI Ayog, 2017).

\section{Performance of New Policies}

Technology Acquisition Scheme of MSME launched in 2015-16, has benefitted 5,047 MSEs under Credit Linked Capital Subsidy Scheme. About 20 percent enhancement in productivity, improved work culture, increased competitiveness, inventory reduction cost saving, etc were observed. Credit Guarantee Scheme of 2015-16, Government of India contributed Rs. 81.36 Crore to the Trust Fund. 513978 MSEs .have been benefitted under the scheme. The Scheme has performed well leading to higher lending without collateral to SMEs. Textile sector has very high employment elasticity. Capacity building in the textile sector for employment generation is set up to reap the demographic dividend. It is proposed that Integrated Skill Development Scheme should be continued beyond 12th Five Year Plan with higher allocation for training 27 Lakhs persons in the mainstream sector and 4.5 Lakhs persons in the traditional/ unorganized sectors. An outlay of Rs. 1980 Crores for next 3 years is proposed. All Handloom sector schemes will merge under National Handloom Development Programme to adopt a flexible and holistic approach in the sector to facilitate handloom weavers to meet the challenges of a globalized environment. Scheme focuses on increasing the income of weavers and sectoral development. The proposed financial outlay is Rs. 2119 Crores for next 3 years. A similar recommendation for the handicrafts sector is also being proposed. All Handicrafts scheme should merge under National Handicrafts Development Programme. Scheme focuses on increasing the income of artisans. The proposed financial outlay is Rs. 890 Crores for next 3 years. Indian leather sector is dominated by small and unorganized industries and thus need assistance to increase production and productivity. Indian Leather Development 
Programme through its sub-schemes aim at augmenting raw material base, address environmental concerns, human resources development, infrastructure constraints and establish institutional facilities The Indian Leather Development Programme will continue with a higher financial outlay of Rs. 5648 crore. The purpose is to upgrade 12 FDDI, skill training to 7 lakh youths, upgradation of 21 CETP \& ETP of 200 tanneries, 9 mega leather clusters, modernization of 1000 units, 7 lakh jobs, higher exports and boost to the domestic manufacturing. The National Career Service is a mission mode project that provides a host of career-related services such as dynamic job matching, career counseling, job notifications, vocational guidance, information on skill development courses, etc. It brings all stakeholders of the project together to facilitate convergence of information and create synergies through these associations. National Career Service seeks to address 3.7 crore job seekers and 14.8 lakh employers ( NITI Ayog, 2017). The Pradhan Mantri Rojgar Protsahan Yojna is a scheme to incentivize employers for job creation, envisaging payment of employers' contribution is under implementation. The government will pay 8.33 percent EPS contribution for new employees earning up to Rs. 15000/- per month. Incentivisation of employers for providing employment to new job seekers would help in fruitful job creation. It intends to create 5 Lakh jobs per annum, which needs to be continued. There is a possibility of convergence of skill development schemes of Ministry of Tourism with the schemes of Ministry of Skill Development. The Ministry of Tourism under the program titled 'Hunar Se Rozgar Tak' conducts training courses across the country to create employable skills amongst youth who are minimum eighth pass and in the age group of 18 to 28 years. The Programme is being implemented by a number of organizations including the Institutes of Hotel Management, Food Craft Institutes, State Tourism Development Corporations, classified hotels and the Indian Institute of Tourism \& Travel Management. Presently, this program covers hospitality trade namely; food production, food and beverage service, bakery and housekeeping and few other tourism specific areas. The Scheme of Hunar Se Rozgar Tak been transferred to the Ministry of Ministry of Skill 
Development and Entrepreneurship .Prime Minister's Rural Employment Cluster Yojana: providing comprehensive rural industry development is to be launched to start Rural Employment Clusters / small industrial estates at 50 places in rural areas giving impetus to agro-industry and employment involving academic institutions, administrative machinery of Central, State and local administration. In order to strengthen the weaving sector, additional incentives for modernisation of power looms, uniform concessional power tariff are required to make the sector competitive. A new scheme of Integration Scheme for Power loom Sector is proposed which aims to attract Rs. 1000 crores investments, 10,000 jobs and upgradation of power loom Sector. The financial outlay for this project is Rs. 487 Crores in 3 years. It is proposed to create Infrastructure for supporting infrastructure critical for promoting exports. Under new scheme of Trade Infrastructure for Export Scheme, financial support will be given to Export Infrastructure Projects executed by Central and State Agencies (NITI Ayog, 2017).

According to the Planning Commission, about 12.8 million people will join the labour market annually up to 2017 . As the proportion of the working age group of 15-59 years increases, India has the advantage of a "demographic dividend". Harnessing the demographic dividend through appropriate skill development efforts would provide an opportunity to achieve inclusion and enhance productivity within the country and also effect a reduction in global skill shortages. More than 700 million Indians are estimated to enter the working age group by 2022, of which more than 500 million will require some form of vocational or skill training. Large scale skill development is thus an imminent imperative. India has very high shortage of skill in the globe. Thus, it is imperative to create an effective ecosystem of skill development of youth in order to make in India vision a success.

\section{Challenges in Skill Development}

- Skill is still not aspirational and is viewed as the last option meant for those who have not been able to progress/opted out of the formal academic system. 
Currently there is no opportunity of vertical or horizontal mobility within the skill ecosystem.

- One of the major reasons why skills are not aspirational today is because it is not seen as a stream of education but a decision of circumstances. It is crucial to align skill education with academic education so that it is perceived as an alternate source of education.

- There is no credit system in skill education or academic education eco- system which would allow someone to use the training done in skill education system in the academic education system.

- There are no institutes providing high end courses in skilling to provide some one the opportunity to advance his/her skill in order to improve the monetary reimbursement.

- There are no vertical growth pathways on the lines of the general education system, so that skill education and training is also seen as a valid route to earn degrees and diplomas, and consequently to positions of authority linked to such qualifications.

- Currently only 30 percent of skilled manpower consist of women. Thus, there is huge deficit in skill training in gender perspective.

- Indian Institute of Skills will act as higher institutes of skill development similar to IITs for technical education. These Institutions will prepare the workforce of higher order skill courses which will provide progression pathway in skills education equivalent to at least the graduate level in academic education system. These institutes will impart high-end skills with state of the art infrastructure to prepare the Indian workforce for the upper spectrum of skill requirement and also for the job requirement of the future.

- Five Indian Institute of Skills are planned to be set up in 5 regions of India. The foundation stone for the first Indian Institute of Skill was laid in Kanpur in December, 2016. 


\section{Suggestions}

- There is an urgent need to reorient the skill development to face industry. There is a need for a more objective assessment of the skill gap within the country as well as in the overseas market to provide job opportunities and cash in on the demographic dividend.

- The curriculum will have to be suitably modified to address the emerging opportunities on account of introduction of technology, higher automation and consequently more and more creative ways of service delivery.

- The economy has shifted towards knowledge-intensive, service based industries, in which patterns of employment are more flexible and individuals must learn to thrive in a more fluid, unpredictable environment. Focus areas for training would be (1) e-commerce, Iinternet, cloud computing; (2) digital platforms for providing variety of services; and focus on semi-contractual and self-employment .

- It is also desirable that Ministry of Human Resource Development should begin the process of aligning the curriculum of technical educational institutions to incorporate needs of industry technologies in order to prepare the future workforce to be ready with right skill sets.

- There is a need to create a portal for a knowledge repository on the R\&D initiatives. The common online database would record the innovations (both process and product) happening across India. All Government R\&D institutions, interested private R\&D institutions can be brought onto this platform which will have details of R\&D initiatives taken up by different institutions and the stage of the research.

- If India's demographic dividend has to be channelized in the most productive directions, then government approach to recognizing the potential in the services sector has to be realized. . There is ample opportunity for multiplying job creation in different services sector. Considering the fact that employment creation 
will be the maximum in services sector, there is a need to develop an action plan for ensuring services export.

- There is a need to develop the current training capacity which and better utilize the existing capacity in order to provide quality skill education to the youth of India. There are over 10 lakh institutional buildings which being used less than 40 hours a week. Proper schemes and policy need to be developed to better utilize this tremendous hard and soft infrastructure asset available with us.

- Skill ecosystem is developing, and with multiple stakeholders getting involved in the ecosystem such as the Ministry, Private training partners, Government training institutions and institutions formed through PPP such as NSDC it is required to have a regulatory authority which is at arm's length .Thus as NSDA is not directly involved in the training ecosystem it is suggested to restructure it to a skill regulatory authority which can regulate the newly developed skill ecosystem.

- Strengthening the infrastructure to facilitate the all round development of the small and micro business is the need of hour. This requires development of adequate infrastructure such as roads, connectivity power, transportation etc. Giving piloting role in establishing infrastructure in the state may encourage private sector.

- Universities, Colleges and well established institutes of learning, education and research including NGO's may be promoted to start the Training Centers because they have plenty of experienced, qualified and competent faculties well equipped and enriched libraries, hostel and other infrastructural facilities.

- All the universities, Degree \& Post Graduate Colleges, deemed universities should establish a separate section for Skill Development for facilitating and providing career guidance. Importantly, these centers should be established till for individual career counseling, up gradation of skills, motivation and mobilization of aspirants for various sectors of training.

- Girls/Women from Scheduled Castes, OBCs and minorities 
should be given preference in enrolment in such skill training institutions. They should be provided social security, separate toilet facility, and hostel and individual career guidance so that they may join the mainstream and avail the reservation benefits.

- It is suggested that reading materials should be developed by the skill training institutions in consultation with academic experts. The reading materials in proper shape (modules, papers, monographs and reports) should be provided time to time to the students so that they may go through the reading materials in advance and participate effectively in the discussions and deliberations in classrooms. The skill training institutions may approach to the academic experts for developing a feedback form for the assessment of the faculty.

- Skill training institutions should emphasize on institutional efforts for placement services. The data bank for private and corporate sectors may be prepared in advance where students may be placed besides compiling and display of information on competitive examinations and various career opportunities.

- There should be more focus on placement services such as organizing of job fairs, conduct of mock interviews, group discussions, expose visits, and on job training. Besides, training centres should ensure proper tracking of students/ candidates after placement.

- In order to have transparency and fairness in selection of candidates, every center of training partner should constitute a selection committee comprising of members such as GM DIC, Manger Lead bank, District Employment Officer, BDOs, MIS Managers, Village Pradhans, and Representatives of NABARD along with representation from local industry/business associations. This will be also helpful in ensuring high retention rate and will reduce cases of dropouts. Those centres that have not yet constituted the Selection Committee should be asked to do so immediately.

- It is suggested to ensure quality training, a pool of qualified and 
experienced trainers should be developed and maintained at State Programme Management Unit (SPMU) Level for all sectors of training and TOTs should be conducted by SPMU with the help of Industry and subject expert. It should be mandatory that at least one trainer of the concerned sector should be deployed from the pool of trainers.

\section{References}

Acszolton, et.al., The Entrepreneurial Advantage of World Cities: Evidence from Global Entrepreneurship Monitor Data, Scientific Analysis of Entrepreneurship and SMEs, www.enterpreneurship-smes.eu

Athena Infonomics (2017) Skill Development in India: Challenges and Opportunities, Athena Infonomics, New Delhi

Chenoy, Dilip (2012) Skill Development in India: A transformation in The Making, India Infrastructure Report, Oxford University Press, New Delhi

CII ( 2015) Skill Development and Productivity of Workforce, CII, New Delhi

Clark, P. (2005) Technical and Vocational education Systems in Australia and India : An Experiment in Cross Cultural Learning, World Bank, , New Delhi

Dahlam, Carl and Anuja, U. (2005), India and the Knowledge Economy: Leveraging Strengths and Opportunities, World Bank, Washington, DC.

Diwakar, Nitika and Ahmed Tafique (2015) Skill Development of women through Vocational training, International Journal of Applied Research, Vol, 1 (6)

Fazalbhoy, Sabiha (2014) Women Entrepreneurship as the Way for Economic Development, Annual Research Journal of Symbiosis Centre for Management Studies, Pune, Vol. 2, Issue 1, March .

FICCI (2015) Skill Development in India , Konrad Adenaur Stiftung FICCI, New Delhi

FICCI(2015) Skill development in India, FICCI, New Delhi

Government of Gujarat(2017) Skill Development Sector Profile , Government of Gujarat,Ahmadabad

Government of Karnataka (2016) Skill development Policy for Karnataka, Government of Karnataka

Gupta, A. K. and Singh, A. K (2015) Women Entrepreneurship In India: Schemes, Problems and Way Forward, International Journal of 
Management Research and Technology, Volume 9, Issue 2, July December

IBER (2013) Skill Development Initiatives in India, IBEF, New Delhi

IFC ( 2014) Improving Access to Finance for Women Owned Business in India , International Finance Corporation, World Bank, New Delhi

Krishna, G.R, et. al,(2011) (Edited) Entrepreneurship And Development, SITA Publications, Mumbai

MSDE (2015) National Skill development Policy, Ministry of Skill development and Entrepreneurship, Government of India, New Delhi

NITI Ayog (2017) Report of the Group of Secretaries on Commerce and Industry, NITIAyog, Government of India, New Delhi

NITI Ayog (2017) Report of the Group of Secretaries on Education and Social Development, NITI Ayog, Government of India, New Delhi

NSDC ( 2013) Human Resource and Skill Requirements in Education and Skill Development Sector, NSDC, New Delhi

Okada, Aya (2012) Skill Development for Youth in India : Challenges and Opportunities, Journal of International Cooperation, in Education, Vol. 15(2)

Ponsindhu, and Nirmala , S ( 2014) Role of MSME in Women Entrepreneurial Development, International Journal of Research and Development, Vol2 (4)

Prabhavathi, P. O, and Bhasav Raja, M. G. (2016) Women Empowerment through Udyogini Scheme in Karnataka, Journal of Humanities and Social Science, Vol. 21(8)

Ramakishna K, and Sudhakar, A ( 2015) Women Empowerment though Skill Development: The Role of RUDSETIs, International Journal in Management and social science, Vol.3( 6)

Singh , A. K. (2015) Implementation of National Urban Street Vendors Policy and Legal Framework in India, International Journal of Information Systems and E- Business Management, Vol. 4(2)

Singh, A. K. (2017) Monitoring, Evaluation and Impact assessment of UPSDM, Project Report, Hi Tech. Insititute of Information Technology, Ghaziabd, Uttar Pradesh

Singh, A.K. (2009), Role of Entrepreneurship Development in Urban Poverty Alleviation, Training Module, Regional Centre for Urban and Environmental Studies, Lucknow.

Trivei, M. P, and Gaur Ashok (2015) The Role of Women Entrepreneurs 
in Micro , Small and Medium Enterprises, Pacific Business Review International, Vol. 7 (7)

Verma , Bhavana ( 2015) Challenges of Skill Development and Rural Women Entrepreneurship , International Journal of Multidisciplinary Research in Modern Education, Vol,. 1(1)

World Bank (2006), Skill Development in India: The Vocational Education and Training System, Human Development Unit, South Asia R 